\title{
The Production of stable Potent Preparations of Penicillinase
}

\author{
By E. S. DUTHIE \\ The Lister Institute, Elstree, Herts
}

SUMMARY: Optimal yields of penicillinase were obtained by the continuous addition of penicillin to cultures of certain strains of Bacillus subtilis during their logarithmic growth phase.

Lower yields of enzyme were obtained if the penicillin was added when growth had ceased or to partly grown cultures kept at rest and subsequently shaken.

Partial lysis of the bacteria was accompanied by an increased yield of enzyme, but complete lysis appeared to result in partial destruction.

Various authors, beginning with Abraham \& Chain (1940), have shown that the ability of certain bacteria to destroy penicillin is due to the production of an enzyme penicillinase. Gram-positive bacteria of the subtilis group (cf. Bacillus subtilis or B. licheniformis, Duthie, 1944; Lawrence, 1944, 1945a, $b$; Ungar, 1944; Bacillus cereus, Benedict, Schmidt \& Coghill, 1945; LePage, Morgan \& Campbell, 1946) produce the enzyme in a stable extracellular form in considerable amounts, and culture filtrates of these organisms are therefore very suitable for removing penicillin in the sterility testing of penicillin batches and in recovering pathogenic bacteria from body fluids containing penicillin. In all cases it is important that the enzyme solution used should be of high potency, so that the penicillin present may be rapidly destroyed with as little attendant destruction as possible of any micro-organisms present.

In 1944 I showed that the addition of penicillin to cultures of $B$. subtilis, N.C.T.C. 6346 , resulted in a $20-30$-fold increase in the enzyme content of the culture fluid. Benedict, et al. (1945) obtained very high yields using strains of $B$. cereus grown in cultures of penicillin-producing strains of Penicillium notatum and P. chrysogenum. It was necessary to obtain a balance between the growth of bacteria and fungus, and the high yield was undoubtedly due to an enzyme adaptation as the result of penicillin production by the latter. Recently LePage et al. (1946) found that very high yields of penicillinase may be obtained by the gradual addition of penicillin in three stages to a previously aerated culture of the B. cereus, strain N.R.R.L. 569, used by Benedict et al. (1945). Growth was maintained for four days. The authors obtained partial purification of the enzyme by adsorbtion on to Hyflo Super-Cel (Johns Manville Ltd.), followed by elution with dilute ammonia and precipitation between 50 and $100 \%$ saturated ammonium sulphate.

More recently in two papers Housewright \& Henry (1947 $a, b)$ have described their method of producing penicillinase from this same organism, N.R.R.L. B 569. The yields of enzyme obtained were not very high, although they added large amounts of penicillin both initially and after $24 \mathrm{hr}$. growth.

My experiments over the past two years with two strains of $B$. subtilis have 
shown that penicillinase of high potency could be obtained consistently by the continuous addition of penicillin to shaken cultures, and large numbers of batches suitable for routine use have been made in this way. Although the enzyme yield is comparable with that obtained by Benedict et al. (1945) it is not as high as that claimed by LePage et al. (1946). On the other hand, the method is in many respects simpler than that used by either of these authors, since one single penicillin addition over a period varying from 2 to $24 \mathrm{hr}$. is sufficient and the results are very consistent. In addition, by varying the conditions it has been possible to make certain observations on the nature of the processes involved.

\section{METHODS}

Organisms used. Almost all the experiments were carried out with two strains of a subtilis-like organism, B. licheniformis, one the N.C.T.C. strain 6346 previously used, and another made available through the kindness of $\mathbf{M r} \mathbf{R}$. F. Hunwicke and now entered in the National Collection of Type Cultures as strain no. 7198. This latter strain produced approximately twice as much penicillinase as did no. 6346 under all the conditions tested, and was equally constant in its behaviour. A comparison of the penicillinase-producing properties of five strains of $\boldsymbol{B}$. subtilis and of seven strains of $\boldsymbol{B}$. licheniformis obtained from the National Collection of Type Cultures showed that penicillinase production was not determined by the species. The highest yield of these twelve strains was given by $B$. subtilis N.C.T.C. 85, two strains of B. subtilis and five of $B$. licheniformis gave moderate yields, while two of each species gave little or none under the same conditions.

In addition, a few experiments were made with a strain of B.cereus, N.R.R.L. B569, obtained from Dr R. G. Benedict, and used in his experiments (Benedict et al. 1945).

Culture methods. Since the majority of cultures were shaken at some stage in their growth it was found convenient to use either Ehrlenmeyer flasks containing about one-fifth of their volume of medium, or penicillin flasks with side spouts containing $200 \mathrm{ml}$. of the culture fluid. Continuous movement of the medium was secured in either case by placing the vessels on a horizontal table made to revolve eccentrically about 60 times/min. by means of a motor.

Since Lemco broth $(\%(\mathrm{w} / \mathrm{v})$ : peptone 1 ; Lemco meat extract $1 ; \mathrm{NaCl}, 0.5)$ gave yields of enzyme which were consistently as high as those obtained with other media tested, this was used in all the experiments. The flasks were usually seeded and grown at rest for several days before experiments were made. Under these conditions shaking greatly increased the turbidity, bringing about a 5- to 10-fold increase in the number of bacteria present.

Penicillin was added continuously to penicillin flasks by means of a Eudrip no. 2 apparatus similar in principle to the no. 3 type described by McAdam, Duguid \& Challinor (1944). In these experiments the penicillin flasks were fitted with rubber bungs containing two pieces of glass tubing, one plugged with wool and one covered with a rubber cap, and the penicillin was allowed to trickle in from the Eudrip apparatus through a hypodermic needle pushed 
through the rubber cap. The flasks and rubber bungs must be sterilized separately to prevent damage to the flasks.

Before assays of enzyme content were made, culture samples were freed of organisms by centrifuging, diluted $1 / 20$ in neutral buffered gum arabic $\mathrm{pH} 7 \cdot 0$, and filtered in $8 \mathrm{ml}$. amounts through a $4 \mathrm{~cm}$. Gradocol membrane of pore size about $0.64 \mu$. A number of samples could be filtered in succession through the same membrane with a consequent saving in time and expense. Large batches were successfully cleared by filtration through paper after the addition of Super-Cel and were then easily sterilized by filtration.

Estimation of penicillinase content. Two methods were used:

(1) Penicillinase to a final concentration of $1 / 20,000$ was added to nutrient broth heavily seeded with the Oxford strain of Staphylococcus aureus and containing varying concentrations of penicillin such as 5, 10, 20, 50, 100 and 200 units $/ \mathrm{ml}$. The intermediate penicillinase dilutions were made in sterile nutrient broth and were incubated as a check on the sterility of the original enzyme solution. The mixtures of penicillin, enzyme and staphylococci were incubated for $24 \mathrm{hr}$. at $37^{\circ}$, and the activity of the enzyme was recorded as the number of units of penicillin destroyed by $1 \mathrm{ml}$. of $1 / 20,000$ penicillinase, i.e. $0.0005 \mathrm{ml}$, enzyme as shown by the growth of the seeded staphylococci. This method was sometimes invalidated by the presence of chance contaminants and was therefore not as reliable as the second method.

(2) Falling dilutions of filtered penicillinase were added to 100 units of penicillin in $\mathrm{M} / \mathbf{1 5 0}$ phosphate buffer in $1 \%$ gum arabic at $\mathrm{pH} \mathbf{7 \cdot 4}$. The mixtures were incubated for $1 \mathrm{hr}$. at $37^{\circ}$, after which samples were placed in cylinders on staphylococcal seeded plates as in the penicillin assay method described by Heatley (1944) and placed in the incubator. All dilutions were made in sterile solutions, although this is probably not necessary, and results were expressed as the smallest volume of the original solution which brought about complete destruction of the penicillin as shown by the absence of an inhibition zone. The method is similar to that described by the present author in 1944 and used subsequently by various workers, although the penicillin concentration and time of incubation is different.

\section{RESULTS}

Influence of adding penicillin continuously. In previous studies (Duthie, 1944) it was demonstrated that the addition of penicillin to a fully grown culture of $B$. subtilis 6346 grown at rest increased the yield of penicillinase some 20 - to 30 -fold. The only effect of continuous shaking following or during the addition of penicillin was to accelerate the rate of formation of penicillinase without appreciably increasing the final yield. In these early experiments the penicillin was added in single amounts after 12,24 or $48 \mathrm{hr}$. growth. Since it was obvious that under these conditions penicillinase was present in sufficient amounts to destroy the added penicillin very rapidly and increasing the amount of the penicillin added in this way did not affect the final yield, the effect of adding penicillin continuously over $12-24 \mathrm{hr}$. was now investigated with the results shown in Table 1. 
Table 1. Effect of adding 10,000-15,000 units penicillin in $100 \mathrm{ml}$. saline in various ways on the production of penicillinase from Bacillus licheniformis, N.C.T.C. strains 6346 and 7198

All cultures were grown in $200 \mathrm{ml}$. Lemco broth 3-5 days at rest before the addition of penicillin. Temperature 22-26 ${ }^{\circ}$.

\begin{tabular}{|c|c|c|c|}
\hline Penicillin added & $\begin{array}{c}\text { Condition } \\
\text { during addition }\end{array}$ & $\begin{array}{c}\text { Units of penicillin } \\
\text { inactivated by } \\
0.00005 \text { ml. enzyme } \\
\text { solution in } 24 \text { hr. at } 37^{\circ} \text {. } \\
\text { Method } 1\end{array}$ & $\begin{array}{c}\text { Vol. of enzyme } \\
\text { solution required to } \\
\text { inactivate } 100 \text { units } \\
\text { penicillin in } 1 \mathrm{hr} \text {. } \\
\text { at } 37^{\circ} \text {. Method } 2 \\
\text { (ml.) }\end{array}$ \\
\hline Continuously & Shaken & $100-150$ & $0 \cdot 0002-0 \cdot 0015$ \\
\hline Continuously & Rest & 6 & - \\
\hline $\begin{array}{l}\text { In one lot at beginning } \\
\text { of shaking }\end{array}$ & Shaken & 20 & - \\
\hline 6 lots over $36 \mathrm{hr}$. & Shaken & 20 & 0.004 \\
\hline 6 lots over $36 \mathrm{hr}$. & Rest & 5 & 一 \\
\hline No penicillin added & Shaken & $<0.5$ & - \\
\hline
\end{tabular}

It will be seen that when penicillin is added continuously and the culture is agitated during its addition the final yield of enzyme is much greater than that obtained in any other way, being some ten to twenty times as powerful as when the penicillin is added in one single amount at the beginning of shaking or in six equal amounts over a $36 \mathrm{hr}$. period. Cultures kept at rest yielded even less.

Table 2. Penicillin in $100 \mathrm{ml}$. saline added continuously to $200 \mathrm{ml}$. of a shaken broth culture of Bacillus licheniformis, N.C.T.C. 6346 at $26^{\circ}$

Culture grown at rest. Shaken during penicillin addition and allowed to lyse later.

$\begin{array}{cc} & \begin{array}{c}\text { Units penicillin inactivated } \\ \text { completely by } 0 \cdot 0005 \mathrm{ml} .\end{array} \\ \text { Units penicillin } & \begin{array}{c}\text { penicillinase in } 24 \mathrm{hr} . \\ \text { added }\end{array} \\ 100,000 & \text { at } 37^{\circ} \text {. Method } 1 \\ 50,000 & 6 \\ 20,000 & 25 \\ 10,000 & 50-100 \\ 5,000 & 50-100 \\ \text { None } & 12 \\ & 2\end{array}$

Amount of penicillin added and time of addition. In all the experiments in Table 1, 10,000-15,000 units of penicillin in $100 \mathrm{ml}$. of saline were added and (Table 2) this was optimal for the amount of culture used $(200 \mathrm{ml}$.). This final value of 50 units penicillin $/ \mathrm{ml}$. of culture is curiously enough similar to that adopted by LePage et al. (1946), but is one-eighth of that added by Housewright \& Henry $(1947 a)$. A few experiments showed that the period over which penicillin is added continuously should lie between 2 and $24 \mathrm{hr}$. and that there was little advantage in prolonging the time over the $24 \mathrm{hr}$. period.

Treatment of cultures before, during and after the addition of penicillin. The highest and most constant yields were obtained when penicillin was added 
continuously to a culture first grown at rest and then shaken to ensure further growth during the addition of penicillin (Table 3 ). The yields were sometimes as high, but were less consistently so when penicillin was first added some $12 \mathrm{hr}$. after shaking had begun, by which time the culture had reached maximum growth. Much lower yields were obtained if the penicillin was added to an unshaken (partly grown) culture at rest and the culture shaken subsequently. After shaking and adding the penicillin it was found advantageous to leave the

Table 3. Effect of adding penicillin to different grozth stages of culture on enzyme yield

Strain no. 7198 . Temperature $37^{\circ}$ Condition of growth

Before penicillin
addition
(1) Rest $18 \mathrm{hr}$.
(2) Rest $18 \mathrm{hr}$.
(3) Shake $18 \mathrm{hr}$.
(4) Shake $18 \mathrm{hr}$.

\section{During penicillin} addition

Rest $18 \mathrm{hr}$. Shake $12 \mathrm{hr}$. Rest $12 \mathrm{hr}$. Shake $12 \mathrm{hr}$.
After penicillin addition

Shaken $12 \mathrm{hr}$.

Rest 6 hr.

Measured at once

Rest 6 hr.
Filtrate concentration giving complete destruction of 100 units $\mathrm{ml}$. in $1 \mathrm{hr}$. at $37^{\circ}$. Method 2 $<1 / 500$ $1 / 2000$

$1 / 1000$

$1 / 1000$

Table 4. Effect of lysis on penicillinase yield strain, N.C.T.C. 6346 at $26^{\circ}$

Culture grown at rest; shaken during penicillin addition and allowed to lyse later. Units penicillin inactivated by $0.0005 \mathrm{ml}$.

Units
penicillin
added
20,000
10,000
5,000
penicillinase in $18 \mathrm{hr}$. at $37^{\circ}$. Method 1

$\begin{array}{ccc}\text { Measured } & \text { After } 24 \mathrm{hr} . & \text { After } 7 \text { days } \\ \text { immediately } & \text { rest or shaken } & \text { at rest } \\ 12.5 & 50 & 100 \\ 12.5 & 50 & 100 \\ 12.5 & 12.5 & 100\end{array}$

cultures at rest for several days at $26^{\circ}$ (Table 4) or for $6-12 \mathrm{hr}$. at $37^{\circ}$. During this time lysis occurred most completely and rapidly in those flasks to which penicillin had been added. Cultures of no. 6346 became almost clear, and those of no. 7198 showed partial clearing. It was noted that complete clearing in the case of 7198 resulted in a lower yield of penicillinase than that obtained if only partial lysis occurred, suggesting that while lysis may result in the liberation of the enzyme it may also bring about its partial destruction.

Temperature. Equal enzyme yields were obtained at 26 and at $37^{\circ}$, but the former was preferred, since it gave more consistent results. The periods needed to obtain optimal results were in general much shorter at $37^{\circ}$, and Table 5 shows those periods which gave optimal results for the temperatures indicated.

The amount of inoculum used did not matter within wide limits provided that before the addition of penicillin growth was sufficiently vigorous to ensure that it was not suppressed by the addition of the antibiotic.

Media. Equally good results were obtained on infusion digest and on a meatextract broth such as Lemco. An acid-hydrolyzed casein medium similar to that used by Rogers (1945) gave about half the yield obtained on the other media and the enzyme was less stable when diluted. The addition of glucose to the Lemco broth medium used was without effect. 


\section{Production of penicillinase}

Deep fermentation. Heavy suspensions of both subtilis strains were obtained by the continuous passage of air through a $12 \mathrm{l}$. bottle containing $4 \mathrm{l}$. of Lemco medium. The suspensions failed to lyse although penicillin was added continuously during the growth phase, and neither the culture fluid nor the crushed organisms gave a high yield of penicillinase.

Table 5. Conditions for optimal production of penicillinase

10,000 units penicillin added continuously to $200 \mathrm{ml}$. medium.

$\begin{array}{cccc}\text { Temperature } & \text { Period of growth } & \begin{array}{c}\text { Duration of } \\ \text { penicillin addition }\end{array} & \begin{array}{c}\text { Period of incubation } \\ \text { after penicillin }\end{array} \\ { }_{37} & \text { at rest } & 6-24 \mathrm{hr} . & 6-12 \mathrm{hr} . \\ 26 & 12-24 \mathrm{hr} . & 12-36 \mathrm{hr} . & 2-7 \text { days }\end{array}$

Organisms. As previously noted, B. licheniformis, strain 7198 , gave approximately twice the penicillinase yield given by 6346 under identical conditions, and this appeared to be correlated with the fact that it lysed less completely. The strain B. cereus, N.R.R.L. B569, used by Benedict et al. (1945) gave approximately one-twentieth of the maximum given by no. 7198 on the Lemco broth medium. The continuous addition of penicillin varying from 250 to 10,000 units to $200 \mathrm{ml}$. of medium to a penicillinase-producing strain of Staphylococcus did not markedly increase the penicillinase content of the culture fluid.

Comparison of methods of measurement. The methods of assaying penicillinase used by various authors differ so widely through variation of substrate concentration, time and temperature, that it is quite impossible to compare the potency of the different preparations recorded without carrying out a number of experiments. Probably the simplest, if not the most accurate, is to incubate various dilutions of penicillinase with a constant amount of penicillin, and at the end of a given time to assay the solutions for penicillin activity on staphylococcal seeded Petri dishes. The titre may then be taken as the lowest concentration of enzyme giving complete destruction or $50 \%$ destruction of the penicillin. The latter is less easily determined, especially if a biological assay method be the only one available. In the present experiments 100 units $/ \mathrm{ml}$. was the level of penicillin adopted, but if this concentration be varied, as in Table 6 , it will be seen that a much higher substrate level than $100 \mathrm{units} / \mathrm{ml}$. is required in order to reach full activity of the enzyme using either the 50 or $100 \%$ level as an index of enzyme activity. Thus at a penicillin concentration of 100 units $/ \mathrm{ml}$., about half as much penicillin is destroyed by every $\mathrm{ml}$. of enzyme solution as at 1000 units $/ \mathrm{ml}$.

Benedict et al. (1945) found that $0.002 \mathrm{ml}$. of their culture filtrates completely destroyed 100 units of penicillin in $1 \mathrm{ml}$. in $4 \mathrm{hr}$. at $30^{\circ}$, and the batch used in the measurements in Table 6 had approximately the same activity under these conditions. When dialyzed against distilled water $0.0001 \mathrm{mg}$. of this preparation destroyed $50 \%$ of 100 units of penicillin in $1.0 \mathrm{ml}$. of phosphate buffer gum arabic $\mathrm{pH} 7 \cdot 0$ in $3 \mathrm{hr}$. at $30^{\circ}$, which compares favourably with the preparation described by Benedict et al. (1945). On the other hand, LePage et al. (1946) 
found that some of their culture filtrates at $1 / 1,000,000$ gave a $50 \%$ reduction of penicillin solutions in final concentration of 1 unit $/ \mathrm{ml}$. in $1 \mathrm{hr}$. at $37^{\circ}$ and were therefore some $\mathbf{2 5}$ times as active as was the preparation used in Table 6.

Table 6. The influence of the concentration of penicillin
on the activity of penicillinase

Recently, Housewright \& Henry $(\mathbf{1 9 4 7} a, b)$ have shown that penicillinase activity can be measured by following the rate of carbon dioxide evolution from bicarbonate solutions in Warburg manometer vessels to which mixtures of penicillin and penicillinase have been added. In addition, these authors have standardized their enzyme yields biologically by two methods: (a) the destruction of 10 units of penicillin per ml. in broth in $48 \mathrm{hr}$. at $37^{\circ}$ as shown by the development of anthrax spores (maximum titre obtained $=1 / 8192$ ); and (b) the destruction of $57.5 \%$ of 50 units penicillin in $11 \mathrm{ml}$. at $\mathrm{pH} 7.0 \mathrm{in} 1 \mathrm{hr}$. at $37^{\circ}$, the solutions being diluted and plated (method of McQuarrie \& Liebmann (1944) (titre of maximum yield obtained $=1 / 1400)$ ). Under these conditions the preparation measured in Table 5 , which had about half the activity of the best preparations obtained, gave values of $\mathbf{1} / \mathbf{1 5 0 , 0 0 0}$ and $\mathbf{1} / 40,000$ respectively, indicating that it was at least twenty times as potent as those obtained by Housewright \& Henry. The destruction of penicillinase by $\mathrm{Fe}^{+++}$ions noted by these authors (between 5 and $\mathbf{5 0} \mu \mathrm{mg}$. $/ \mathrm{ml}$. levels) has been confirmed. $\mathbf{F e}^{++}$ ions have a similar, but less marked action.

\section{DISCUSSION}

There is little doubt that organisms of the mesentericus-subtilis group are the most potent source of stable cell-free penicillinase, and it is therefore of some importance to learn the conditions under which a highly active penicillinase may be obtained. The formation of the enzyme by these organisms is largely adaptive and would appear to depend on the presence of active substrate in the culture for a period of time varying from 2 to $24 \mathrm{hr}$. during, or at the end of, the logarithmic growth phase. Since penicillin is rapidly destroyed by pure enzyme in the culture medium, substrate must be added continuously in order to produce optimal yields. Benedict et al. (1945) obtained this by growing the bacteria in contact with penicillin-producing fungi and LePage et al. (1946) state that penicillin was added gradually to their cultures on three different occasions.

The value of shaking the cultures before or during the addition is clear, since 
the greatly increased cell population placed in contact with substrate gives a higher penicillinase yield than in those left at rest. It is interesting, in this connexion, that the addition of penicillin to resting cells subsequently shaken does not result in a great increase in the yield of enzyme; there is, therefore, no permanent adaptation transmissible to the daughter cells.

Unfortunately, the relation of enzyme production to lysis is by no means so clear. LePage et al. (1946) noted a fall in the enzyme titre of lysed cultures followed by a rise $24 \mathrm{hr}$. later, and add that if lysis is observed during the addition of penicillin no more penicillin should be added for a further $\mathbf{2 4} \mathrm{hr}$. In the present studies, while it was obvious that some degree of lysis enhanced the penicillin content of the medium, complete lysis was accompanied by a fall and partial lysis gave the highest yields.

My best thanks are due to Mr R. F. Hunwicke, Mr C. E. Coulthard and Dr R. G. Benedict, for strains used in this work. I also wish to thank Dr T. Gibson for identifying the two strains as being $B$. licheniformis, and Miss Rhodes of the National Collection of Type Cultures for her kindness in procuring strains for me.

\section{REFERENCES}

Abraham, E. P. \& Chain, E. (1940). An enzyme from bacteria able to destroy penicillin. Nature, Lond., 146, 837.

Benedict, R. G., Schyidt, W. H. \& Coghill, R. D. (1945). Penicillin VII. Penicillinase. Arch. Biochem. 8, 377.

Duthie, E. S. (1944). The production of penicillinase by organisms of the subtilis group. Brit. J. exp. Path. 25, 96.

Heatley, N. G. (1944). A method for the assay of penicillin. Biochem. J. 38, 61.

Housewright, R. D. \& Henry, R. J. (1947a). Studies on penicillinase. I. J. biol. Chem. 167, 553 .

Housewright, R. D. \& Henry, R. J. (1947b). Studies on penicillinase. II. J. biol. Chem. 167, 559.

Lawrexce, C. A. (1943). Sterility test for penicillin. Science, 98, 413.

Lawrence, C. A. (1944). Action of clarase upon penicillin. Science, 99, 15.

LAwrence, C. A. (1945a). Effect of enzyme preparations upon penicillin. I. J. Bact. $49,47$.

Lawrence, C. A. (1945b). Effect of enzyme preparations upon penicillin. II. $J$. Bact. 49, 57.

LePage, G. A., Morgan, J. F. \& Campbell, M. E. (1946). Production and purification of penicillinase. J. biol. Chem. 166, 465.

McAdam, I. W. J., Duguid, J. P. \& Challinor, S. W. (1944). Systemic administration of penicillin. Lancet, ii, 336.

McQuarrie, E. B. \& Liebmann, A. J. (1944). Studies on penicillinase. Arch. Biochem. 5, 307.

Rogers, H. J. (1945). The conditions controlling the production of hyaluronidase by micro-organisms grown in simplified media. Biochem. J. 39, 435.

Ungar, J. (1944). Penicillinase from B. subtilis. Nature, Lond., 154, 236.

(Received 25 April 1947) 